\title{
The Essential Role of Human Resources Management in Healthcare and Its Impact On Facilitating Optimal Healthcare
} Services.

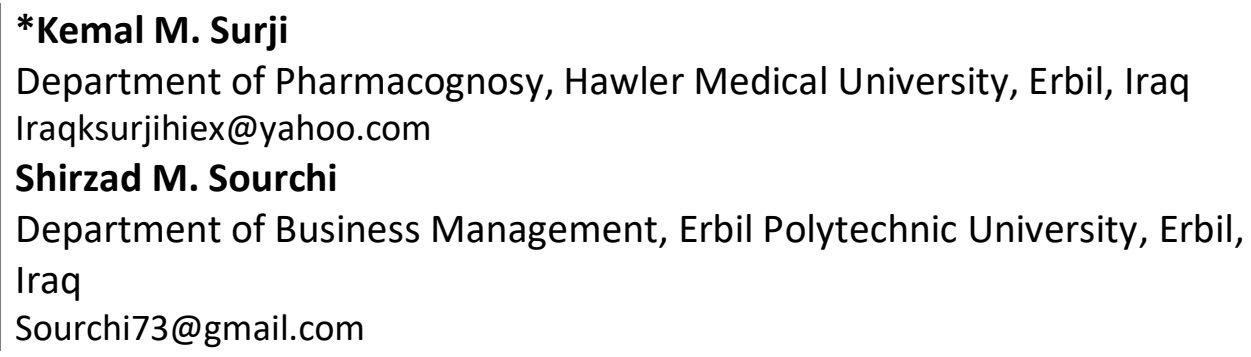

\section{ARTICLE INFO}

\section{Article History:}

Received: 5/3/2020

Accepted: $19 / 5 / 2020$

Published: Spring 2020

Keywords: Human

Resource Management

(HRM), Healthcare

Quality, Healthcare

services Patient

satisfaction, Workforce

performance.

\section{ABSTRACT}

The role of Human resource management (HRM) in the healthcare sector is vital to facilitate optimum healthcare services by improving workforce performance and patient satisfaction. A solid understanding of the role of human resource management and related functions is required to safeguard the delivery of quality service and the success of the healthcare program. The study aims to explore the role and responsibilities of human resource management and its impact on the employee performance and value of healthcare services. The descriptive and investigative methodology was applied to analyze and review the previously published academic literature to obtain the influence of human resource management on the healthcare sector. 
The study illustrates that HRM functions in

Doi:

10.25212/Ifu.qzj.5.2.35 healthcare have a robust effect on facilitating optimal healthcare services and workforce performance, leading to heightening organizational performance. The study recommends that it is imperative to implement effective human resource management plans to achieve higher performance in providing superior healthcare amenities and further enhancement of healthcare organization.

\section{INTRODUCTION}

In the healthcare business, human resources professionals play a critical role in strengthening the healthcare quality services by helping to grow and develop the talent of the industry's workforce. A healthcare institution is a minicommunity that offers services with a passion due to human interaction factors. Human Resources Management in the healthcare organization provides functions that cover everything from performance management to safety, safeguards the delivery of health care amenities, and enabling optimum patient outcomes. Increased implementation of human resource management functions is related to health care administrative operations to develop quality health services globally (Kabene et al., 2006). Mainly, incentives and motivation, safety and welfare of employees, and support initiatives are vital for enhancing the performance of individuals, collaboration, and inspiring organizational culture (WHO 2000).

According to Harris et al.(2007), Human Resource Management is an essential area of management in the healthcare arena, where increase diversity of social backgrounds of both patients and employees require the human 
resource managers to concentrate more on the impact of globalization, technology, and performance training on delivery of healthcare leading to higher quality of patient care. Furthermore, as people provide healthcare services, the role of human resource management remains vital in the improvement of health division (Kabene et al., 2006).

Human resources pursue to enhance the quality of healthcare services and patient satisfaction through technical excellence and socio-cultural value. Hence, professional quality denotes the effect of available health services on society's health conditions (Zum, 2004). Moreover, socio-cultural value measures society's fulfillment through the adequacy of amenities and the capacity to gratify the patient's requirements (Zum, 2004).

Since workforces are considered the most valuable asset of an organization, managers should be concerned with their productivity and performance. To develop a well-organized and capable workforce, the human resource department should provide constant improvement in the strengthening of both individuals and the organization in which they operate. HRM is involved with securing and improving employee's talent as well as enhancing the areas such as job analysis and recruitment, organization and utilization of workforce, healthcare career appraisal and promotion, distribution of employee benefits, implementation of a reward system, motivation and support, and future trends in employees' development. (Keating, 2011).

Job analysis and design is an essential obligation of HR managers to sustain motivation and improve support for the staff. Job design is to develop a set of duties, tasks, and responsibilities that employees should complete. Niles, in his 2012 publication, indicates that in case employees face misunderstanding in terms of the requirements and responsibilities, the overall organizational framework might fail. Hence, stringent distribution of tasks and duties is essential to sustain organizational performance and establishing rheostat.

As far as recruitment and motivation, Muller et al. (2006), states that human resource managers should be competent for efficient problem solving and decision-making skills. He further explains that problem-solving is associated 


\section{QALAAI ZANISTSCIENTIFIC JOURNAL \\ A Scientific Quarterly Refereed Journal Issued by Lebanese French University - Erbil, Kurdistan, Iraq \\ Vol. (5), No (2), Spring 2020 \\ ISSN 2518-6566 (Online) - ISSN 2518-6558 (Print)}

with providing solutions to specific circumstances. Moreover, decision making is significant for administrators to implement proactive facets of management (Muller et al., 2006).

The development of human resource expertise is vital for healthcare personnel to provide superior healthcare service to patients. Therefore, by properly training and developing healthcare employees, healthcare establishments can deliver optimum care for the patients (Ramadevi et al., 2016).

\subsection{Statement of Problem}

Healthcare sectors have been experiencing substantial reformation for the past decade. The structural alteration, cost containment, market mechanisms have been the focus of healthcare organizations for the last 25 years as the significance of human resource management has frequently been overlooked (Townsend and Wilkinson, 2010). Proper management of human resource function is a vital feature of enhancing and sustaining service delivery in the health sector. In various cases, these modifications can be theorized as a measure away from the domination of healthcare sector by specialists and professional knowledge through a concurrent increase in client orientation and justification (Freidson, 1984). There is an impression that states "the consumer is the king, rather than the consultant"; hence, implication to these customeroriented policies have been systematic burdens to justify healthcare production, increase efficiency, and reduce expenses in many frugalities (Korczynski, 2002). Hospitals anticipate reducing their staffing needs to a minimum without compromising the quality of healthcare services. In healthcare, employees expect their organizations to offer infrastructure, human resource functions, and support, which they can associate with amended performance concerning patient care. Contradictory, exertion is kept toward direct care of patients when staff expectations are not met (Hyde et al., 2009)

\subsection{Objectives of the Study}




\section{QALAAI ZANISTSCIENTIFIC JOURNAL \\ A Scientific Quarterly Refereed Journal Issued by Lebanese French University - Erbil, Kurdistan, Iraq \\ Vol. (5), No (2), Spring 2020 \\ ISSN 2518-6566 (Online) - ISSN 2518-6558 (Print)}

A solid understanding of the human resource management functions and issues is required to safeguard the delivery of quality service and the success of the healthcare program. Thus, this study is conceptual in nature, and exploratory method is being used to evaluate the previous literature to fulfill the following objectives:

- To assess the vital functions and responsibilities of HRM in healthcare organizations.

- To analyze the impact of HRM on the value of healthcare service.

- To identify the effect of HRM on employee performance in healthcare institutions.

\subsection{Importance of Study}

The importance of human resources management is a strategic method to manage the staff effectively for better performance. Furthermore, through a caring and open management model, HRM motivates and develops the workforce so they can provide the utmost effort to support the various departments.

Organizations, in general, are comprised of people obtaining their services, developing their skills, inspiring them to high levels of performance, and safeguarding that they continue to uphold their obligation to the organization and to accomplish organizational objectives. This is true irrespective of the nature of the institution, whether governmental, commercial, academic, healthcare sector, recreation, or social action.

HRM in the healthcare sector must perform in a division with some exceptional features such as relatively large staff with various and distinct occupations. Nevertheless, the success of every organization depends on attaining and retaining decent people. Therefore, effective human resource management plays a decisive role in the operation of a successful healthcare system.

Well managed human resource department is vital in the employment and retaining of the clinical and non-clinical workforce, preserving employee 


\section{QALAAI ZANISTSCIENTIFIC JOURNAL \\ A Scientific Quarterly Refereed Journal Issued by Lebanese French University - Erbil, Kurdistan, Iraq \\ Vol. (5), No (2), Spring 2020 \\ ISSN 2518-6566 (Online) - ISSN 2518-6558 (Print)}

morale, providing opportunities for professional growth, and in the ability of the healthcare sector to facilitate optimal healthcare service to enhance patients' health outcomes. Hence, organizations use human resource management functions as critical strategic apparatuses for encouraging satisfactory conduct between workforces and leveraging their knowledge, skills, and abilities, which should upsurge productivity and performance (Sun and Nam, 2011).

\section{Materials and Method}

This article is based on the descriptive analysis and the review of continuing academic literature to obtain the impact of human resource management on healthcare services. The study is theoretical in nature, and the investigative method is being utilized to justify the following three vital aspects relating to HRM in the healthcare sector: 1 . the useful role of human resource management in healthcare, 2. the impact of HRM in facilitating optimal healthcare services, and 3. Effect of HRM on employee performance in health institutions. Thus, the paper is conceptual, and literature is explored and analyzed by collecting data from reviewing previous published research articles and books. The authors searched Google Scholar, PubMed, Cochrane database, and Science Direct for articles published in English.

Journals were searched in mid-2019 and were required to meet two inclusion conditions: (1) to cover at least one of the context-specific keywords and (2) at least one of the topic-related keywords features as a significant discussion point. Authors initially screened the article titles and abstracts, then eliminated any publications that did not meet the conditions, then retrieved full manuscripts for the remaining papers and tested again using the keywords related to the topic. Moreover, references within publications were examined to find supplementary sources. Since the review was desk-based (desktop study), the ethical endorsement was not required.

\section{Literature Review}

The role and the influence of human resource management on the value of healthcare service have been discussed in numerous inquiries. Such functions 


\section{QALAAI ZANISTSCIENTIFIC JOURNAL \\ A Scientific Quarterly Refereed Journal Issued by Lebanese French University - Erbil, Kurdistan, Iraq \\ Vol. (5), No (2), Spring 2020 \\ ISSN 2518-6566 (Online) - ISSN 2518-6558 (Print)}

as HRM strategic planning, hiring, training and education, performance evaluation, motivation, rewards, and other incentives have been the focus of many studies. Furthermore, the studies have covered the elements affecting the performance of the workforce in healthcare organizations. In the subsequent segments, the authors reveal some of the essential literature that studied human resource management in the healthcare division.

\subsection{Definitions of Human Resource Management}

$\mathrm{HRM}$ is an area of the institution that is concerned with the management of people. Human resource management deals with employee relations of an organization starting from recruitment to Employment relation. Furthermore, it is a process of attainment, development, incentive, inspiration, and maintenance of human resources of an organization. Consequently, numerous authors have defined human resource management in a different manner and varying degrees of intricacy. Some of the more expressive definitions of HRM are quoted as follow:

Armstrong (2006): "Human resource management is defined as a strategic and coherent approach to the management of an organization's most valued assets, the people working there, who individually and collectively contribute to the achievement of its objectives."

Boxall and Purcell (2011): "Human Resource Management is all those activities associated with the management of work and people in organizations."

Byars and Rue (2006): "Human resource management (HRM) encompasses those activities designed to provide for and coordinate the human resources of an organization."

Frasch, Shadoviz, and Shelly (2009): "Human resource management (HRM) is the process of employing people, training them, compensating them, 


\section{QALAAI ZANISTSCIENTIFIC JOURNAL \\ A Scientific Quarterly Refereed Journal Issued by Lebanese French University - Erbil, Kurdistan, Iraq \\ Vol. (5), No (2), Spring 2020 \\ ISSN 2518-6566 (Online) - ISSN 2518-6558 (Print)}

developing policies relating to them, and developing strategies to retain them."

Heathfield (2019): "Human Resource Management (HRM) is the function within an organization that focuses on the recruitment of, management of, and providing direction and guidance for the people who work in an organization."

As described by authors, in any health care setting, the Human Resources Management fills a variety of workforce requirements that both organizations and employees may come across. Therefore, the role of the HRM department is to manage all facets of operations that are related to people.

\subsection{The vital role of Human Resource Management in healthcare}

Proper management of human resources has a decisive role in the success of healthcare organizations. The human resources department of any healthcare service is accountable for the patients' and employees' relationship with the healthcare unit. Therefore, employee job satisfaction is crucial to provide superior and compassionate care to gratify patients with the healthcare entity. Human resources management is vital in the recruitment and retention of the clinical and non-clinical workforce, providing opportunities for professional development, maintaining staff morale and motivation, and in the ability of a healthcare organization to deliver outstanding health care services and enhance patients' health outcomes. There are seven primary functions of human resources management:

Strategic Planning: a process of coordinating human resources with organizational goals and objectives. Conducting job analyses to determine the explicit requirements of specific jobs and critical personnel and skills needed for the fulfillment of corporate growth (Shi, 2007). 


\section{QALAAI ZANISTSCIENTIFIC JOURNAL \\ A Scientific Quarterly Refereed Journal Issued by Lebanese French University - Erbil, Kurdistan, Iraq \\ Vol. (5), No (2), Spring 2020 \\ ISSN 2518-6566 (Online) - ISSN 2518-6558 (Print)}

Recruitment and Selection involve seeking qualified people to fill the vacant positions. Effective recruitment and selection permit the employment of the most exceptional applicant with the needed skills for the job (Shi, 2007).

Retention: encompasses keeping and motivating personnel to stay with the organization (Schmitz, 2012).

Compensation and Benefits: Compensation comprises whatever the employee receives for his or her exertion. This involves setting up pay systems based on the education, skills, and years of experience needed to perform the job. Similarly, the significant of nonmonetary enticements and rewards are recognized by most organizations and are configuring their benefits packages to contain not only health care, but also vacation time, 401(k) (retirement plans), Stock purchase plans, Bonuses, Childcare services, Sick leave, Tuition reimbursement and gym membership (Schmitz, 2012).

Performance Evaluation: is the measure of the level of aptitude of an employee compared to a certain standard level of performance, skills, and knowledge (Shi, 2007).

Training and Education: Once an organization hired new employees, they will provide training not only to do their job but also continue to produce and progress innovative skills in their occupation. Training and education increase productivity, employee motivation, and retention (Rivenbark, 2005).

Legal and Regulatory: Human Resource Management must be conscious of all the legal and regulatory laws that affect the work environment, some of these laws are the safety of the workplace, health-care requirements, compensation, and labor laws as well as discrimination (Rivenbark, 2005). 


\section{QALAAI ZANISTSCIENTIFIC JOURNAL \\ A Scientific Quarterly Refereed Journal Issued by Lebanese French University - Erbil, Kurdistan, Iraq \\ Vol. (5), No (2), Spring 2020 \\ ISSN 2518-6566 (Online) - ISSN 2518-6558 (Print)}

According to Robinson (1997), a human resource management role is the delivery of aid and support in HRM matters to line the staff that is directly involved in the organizational production of goods and services. HRM assists in developing employees' skills, encouraging them to higher levels of performance, ensuring their retention and maintenance, as well as their obligation to the organization to accomplish the organizational goals. The human resource management explicit method was proposed by the author consisting of four functions such as recruitment, training and advancement, motivation, and maintenance.

A book chapter entitled "Evolution of human resource management and its role in hospitals" by Sharma and Goyal (2010) expresses that HRM has become a requirement in hospitals. Furthermore, it is imperative to accomplish the practical application of human resources, a desirable working environment, constant development of the workforce, practice highest morale, and employee gratitude in the organization.

According to a study by West et al. (2006), intitled "Reducing Patient Mortality in Hospitals: The Role of Human Resource Management" links human resource management practices to organizational performance and quality of healthcare as an essential subject in the organizational sciences. The authors conducted a survey of 61 directors of Human resource departments of 52 acute hospitals in England regarding HR practices and procedures. The study examined the areas of HR practice, including the extent and style of employee appraisal, staff training, and employee teamwork, as well as data on patient mortality. The article discloses that the utilization of HRM practices has a statistically and practically significant association with patient mortality. Therefore, the findings recommend that managers and policymakers should consider the significance of the role of human resource management systems in health care establishments to improve quality patient care.

Mohebbi et al. (2012), in their research entitled "Analysis of human resource management role in hospitals using Ulrich model," aimed to evaluate the role of human resources in specialized and sub-specialized medical training 


\section{QALAAI ZANISTSCIENTIFIC JOURNAL \\ A Scientific Quarterly Refereed Journal Issued by Lebanese French University - Erbil, Kurdistan, Iraq \\ Vol. (5), No (2), Spring 2020 \\ ISSN 2518-6566 (Online) - ISSN 2518-6558 (Print)}

hospitals of Iran, using Ulrich model. The outcomes of this study show that there is a significant positive relationship between human resources and the quality of services. Thereby, it is recommended to focusing on planning, employee training, and management of health care professionals to improve the capacity of HR managers and the value of healthcare services in the society.

A study entitled "Distributing Human Resource Management Responsibilities: A Classification of Organization," by Valverde and Ryan (2006), intended to express that human resource management is not only the responsibility of human resource departments but also of other internal and external representatives of the organization, such as managers and outside providers. The authors evaluated ways the organization distributes human resource management responsibilities among these representatives. The results of the research illustrate that the model of human resource function implemented by the institution may not be appropriately determined; alternatively, it is a matter of organizational choice. Therefore, businesses choose a suitable type of HRM model they desire and allocate the tasks of their various representatives accordingly instead of being determined by the organizational contingencies.

A study entitled "Role of Human Resource Management in Private Hospitals: A Study of Meerut region." Samaddar et al. (2018), for the purpose of developing a structure for enhancing healthcare services through an effective HRM system. The article evaluates the existing human resource management procedures and provides more effective methods to attain sophisticated levels of employee satisfaction leading to a better quality of patient care. The study provided a questionnaire and interviews with managers, physicians, nurses, and administrators of private hospitals in Meerut region. Out of 150 surveys, 80 forms were completed and considered to be analyzed. The research suggested that policymakers and executives should emphasis on enhancing the role of related human resource management system would be a vital factor to improve patient care in health institutions. 
Townsend et al. (2013), in their article entitled "The Role of Hospitals' HRM in Shaping Clinical Performance: A Holistic Approach," developed and tested a model of human resource management processes impacting hospitals' clinical performance concerning health and safety, strategic management, information management. The authors used multi-rated, industry-based hospital accreditation data relating to 465 hospitals in Australia. They found that in the area of the management process, health and safety, and information systems, the active role of human resource management processes had a significant impact on patient care quality. Furthermore, it was discovered that an effective HRM system substantially moderated the association between strategic management, health and safety, and continuity of patient care quality.

Harris et al. (2007), in their study entitled "Human Resource Management and Performance in Healthcare Organizations," intended to find the links between HRM and performance by comparing the evidence from various literature. The findings revealed the affiliation between human resource management practice, policies, systems, and performance. However, there is a little study exploring the association between human resource management and performance in the healthcare division.

A study entitled "Expanding the HRD Role: Improving employee wellbeing and organizational performance" by Gillbreath and Montesino (2007) was aimed to explain the reason human resource department professionals should be concerned with the well-being of the staff. Furthermore, they deliberate on four main factors that impact the well-being, which are job control, social support, supervisor behavior, and role overload. The authors indicate the expansion of these areas will enhance the quality of life as well as organizational effectiveness. Additionally, it contributes to healthier staff, healthier institutions, and higher recognition of the human resource department's potential for altering the organizations.

In a study by Rondeau and Wagner, (2001), intitled "Impact of human resource management practices on nursing home performance," the effect of human resource management practices and the contingency theory on 283 


\section{QALAAI ZANISTSCIENTIFIC JOURNAL \\ A Scientific Quarterly Refereed Journal Issued by Lebanese French University - Erbil, Kurdistan, Iraq \\ Vol. (5), No (2), Spring 2020 \\ ISSN 2518-6566 (Online) - ISSN 2518-6558 (Print)}

Canadian nursing homes was evaluated by measuring patient and staff satisfaction, operational efficiency, and income. The authors had revealed that the best functioning facilities were those that have implemented "progressive/high performance" human resource management functions and nursing homes that have a workplace environment that staff contribution is strongly valued.

A study entitled "Factors Affecting Human Resource Development in the Iranian Social Security Organization's Hospitals," published by Vahdat S. et al. (2011), was aimed to identify the key elements of HR development utilizing descriptive and applicable methodology. The authors have chosen ninety-six major governmental health organizations as a sample among all the healthcare sectors in Iran. The study revealed that commitment, planning, action and evaluation as central components of HRD, where the conforming features of "commitment (organization development, management commitment, and employment system)" are directly associated with the elements of "planning (career development path and master plan for education)." Furthermore, the results indicated that the path for career development and educational master plan have bilateral relations and unswervingly relate to human resource development functions.

According to an article by Dieleman et al. (2006), entitled "The match between motivation and performance management of health sector workers in Mali," indicates that HRM has a fundamental role in accessibility and quality of healthcare. The authors have defined the elements of motivation and demotivation of employees in healthcare in Mali and linked the motivators to the enactment of performance management. The findings reveal that the critical aspects of motivation were associated with accountability, reward, and recognition, training, and salary. The study illustrates the significance of implementation and enhancement of performance management strategies to effect workforce motivation.

\section{Findings and Discussion}


The study is based on the descriptive analysis and the review of continuing academic literature to acquire the impact of human resource management in healthcare services. Thus, the article is theoretical in nature, and the investigative method is being utilized to justify the active role of human resource management in healthcare and its impact in facilitating optimal healthcare services as well as employee performance in health institutions.

The article explains that human resource management has a significant association with organizational performance; thus, they play a substantial role in organizational effectiveness. The study found that human resource practices play a crucial role in organizational efficiency by maximizing the productivity of the existing resources.

The study shows that human resource management functions in healthcare increase employee satisfaction and productivity, which leads to patient gratification. For example, HRM creates employee training that impacts patient satisfaction; furthermore, effective management style and practice in the healthcare sector lead to job fulfillment and employee retention.

Research reveals that a safe and healthy environment formed by HRM leads to a high-performance work system. Consequently, the performance of staff working in such an atmosphere is much higher than those employed in an unsafe setting.

The article illustrates that coordination and communication among HR managers, middle and line managers are essential since they all are responsible and play a significant role in the enactment of HR policies and practices.

The study reveals that different organizations necessitate different HR models that best suit their requirements based on the nature of the business. Therefore, enterprises choose an appropriate type of HRM model they desire and assign the responsibilities of their various representatives accordingly instead of being determined by the organizational contingencies.

The ultimate function of HRM in any healthcare institution is to enhance the quality of life. Hence, Human resource management in healthcare aims to have competent, inspired, devoted, and committed workforce as well as higher 
productivity, development, and efficiency to provide quality services. Additionally, HRM not only assists employees in obtaining the necessary knowledge and skills to perform their tasks but also divulges their concealed potential to develop them and grow the organization.

HRM creates a culture of trust, collaboration, and strong affiliations among management of various departments and subunits to establish motivation, encouragement, and professional cooperation among the staff. The workforce of healthcare organizations needs competencies such as knowledge, skills, attitude, and moralities so that they continue to deliver high-quality healthcare services in the face of continuous requirements and innovative challenges. Consequently, well established HRM practices are instrumental in achieving organizational objectives and improve productivity.

Human resource management is an important management function in the healthcare division. The principal aim of HRM is the enhancement of organizational performance. Moreover, HRM plays a dynamic role in the success and performance of the healthcare organization. Therefore, human resource management is engaged in securing and developing the talents of employees and applying programs that improve communication and teamwork among the staff to provide optimal performance of the healthcare institution.

The management of human resources is the obligation of all managers in today's competitive business environment. Since the human being is considered as complex and vastly sensitive to the environment, it is safe to say that the most significant issues in an organization are human-related. Therefore, managing human resources in any setting is a challenging mission that requires a good tune human resources to succeed.

The most significant tasks related to human resource management are a strategic plan, job analysis, recruitment, and staffing, measuring work performance, organizing the workforce, appraisal and reward system, retention, training, maintaining, and development of the workforce.

Human resource management in a healthcare institution seeks to augment the quality of services and client satisfaction. Excellence in healthcare is categorized 


\section{QALAAI ZANISTSCIENTIFIC JOURNAL \\ A Scientific Quarterly Refereed Journal Issued by Lebanese French University - Erbil, Kurdistan, Iraq \\ Vol. (5), No (2), Spring 2020 \\ ISSN 2518-6566 (Online) - ISSN 2518-6558 (Print)}

as technical quality, which refers to the effect of available healthcare services on the condition of a population, and Sociocultural quality that measures the level of appropriateness and ability of services to meet patients' expectations. Consequently, as all healthcare services are provided by people, effective HRM will play a crucial role in the success of the healthcare system (Kerby, 2002).

\section{Conclusion}

Human resource management is a vital share of the healthcare organizations in arranging duties and responsibilities as well as employee performance. Managing human resources is crucial for the delivery of efficient and effective healthcare services, ensure client satisfaction, and developing problem-solving and decision-making skills. The research shows that HRM has a robust impact on facilitating optimal healthcare services. Moreover, most literature illustrates the essentials of human resource management in attaining the aim of healthcare institutions and the development of the performance of the workforce through training and motivation to enhance the quality of healthcare amenities that are critical to the success of healthcare sector.

The practice of HRM is beneficial in employee performance and the growth of healthcare organizations. The executives in the hospitals must have a clear strategic plan and objectives to enhance the management of staff in the health institution through proper implementation of the human resource department.

Appropriate management of human resources is vital in providing superior healthcare service. Therefore, effective human resources management plans are imperative to achieve better outcomes from healthcare institutions worldwide.

\section{Recommendations}

Based on the published literature covering the HRM in the healthcare sector, the Author concludes the following recommendations for further enhancement of healthcare organizations: 


\section{QALAAI ZANISTSCIENTIFIC JOURNAL \\ A Scientific Quarterly Refereed Journal Issued by Lebanese French University - Erbil, Kurdistan, Iraq \\ Vol. (5), No (2), Spring 2020 \\ ISSN 2518-6566 (Online) - ISSN 2518-6558 (Print)}

1. Application of the strategic plan for human resource management to improve organizational performance.

2. Development of a reward and recognition program to encourage and motivate the workforce.

3. Management must engage the staff and obtain team input in decision making to empower employees and give them more confidence.

Continuous training and development to enhance employee performance in providing quality service.

Develop a performance evaluation system to recognize the areas of strength and weakness.

Design a positive and safe environment that encourages a positive attitude and behavior to develop more productive professionals.

Create an open-door policy for better communication between employees and management to improve deficiencies.

The issues articulated in many areas and the provided recommendations within this study indicate that these needs should be handled in a precise method to foster an effective and efficient institutional work culture in any health organization to facilitate optimal healthcare services.

\section{REFERENCES:}

Armstrong, M., (2006). Strategic Human Resource Management, A Guide to Action, $4^{\text {th }}$ edition, London: Kogan.

Boxall, P., Purcell, J., (2011). Strategy and Human Resource Management, $3^{\text {rd }}$ edition, London: Palgrave Macmillan.

Byars, L., Rue, L., (2006). Human Resource Management ( $8^{\text {th }}$ ed.). New York, NY: McGraw Hill/Irwin, pp. 371-383.

Dieleman, M., Touré, H., Toonen, J., Martineau T., (2006). The Match Between Motivation and Performance Management of Health Sector Workers in Mali. HR Health 4, 2 doi:10.1186/1478-4491-4-2. 


\section{QALAAI ZANISTSCIENTIFIC JOURNAL \\ A Scientific Quarterly Refereed Journal Issued by Lebanese French University - Erbil, Kurdistan, Iraq \\ Vol. (5), No (2), Spring 2020 \\ ISSN 2518-6566 (Online) - ISSN 2518-6558 (Print)}

Frasch, K., Shadovitz, D., and Shelly, J., (2009). There's No Whining in Human Resource, HR Executive. Online, http://www.hreonline.com/HRE/story.jsp?storyld=227738167. [Accessed September 24, 2019]

Freidson, E., (1984). The changing nature of professional control. Annual Review of Sociology, 10, 1-20.

Gilbreath, B., Montesino, M., (2007). Expanding the HRD Role: Improving employee well-being and organizational performance. Human Resource Development International. 9(4): 563-571 https://doi.org/10.1080/13678860601032684

Harris, C., Cortvriend, P., Hyde, P., (2007). Human Resource Management and Performance in Healthcare Organizations, University of Manchester, Manchester, UK. Journal of Health Organization and Management, 21(4/5).

Heathfield, SM., (2019). Beyond Hiring and Firing: What Is Human Resource Management? Online: https://www.thebalancecareers.com/what-ishuman-resource-management-1918143 [Accessed October 2019].

Hyde, P., Harris, C., Boaden, R., Cortviend, P., (2009). Human relations management, expectations, and healthcare: A qualitative study. Human Relations, 62(5), 701-725.

Kabene, S.., Orchard, C., Howard, J., Leduc, R., Soriano, M., (2006). The importance of HRM in health care: a global context, HR for Health 2006, 4:20. Online: http://www.human-resources-health.com/content/4/1/20 doi:10.1186/1478-4491-4-20. [Accessed October 2019]. 


\section{QALAAI ZANISTSCIENTIFIC JOURNAL \\ A Scientific Quarterly Refereed Journal Issued by Lebanese French University - Erbil, Kurdistan, Iraq \\ Vol. (5), No (2), Spring 2020 \\ ISSN 2518-6566 (Online) - ISSN 2518-6558 (Print)}

Keating, M., (2011). Managing professionals - exploring the role of the hospital Human Resource Function. McDermott A, Cardiff University Business School, Cardiff, UK. Journal of Health Org. \& Mgmt, 25(6).

Kirby, MJL., (2002). The health of Canadians: the federal role. In The Senate of the Government of Canada Volume 6. Ottawa, ON Government of Canada; 2002:78.

Korczynski, M., (2002). HRM in services work. New York: Palgrave Publishing.

Mohebbi, R., Shams, M., Javadi, A., (2012). Analysis of the HRM role in hospitals using the Ulrich model. Afr. J. of Bus. Management Vol. 6(50), pp. 1194311952. Online at http://www.academicjournals.org/AJBM. DOI: 10.5897/AJBM12.074 [Accessed November 2019].

Muller, M., Jooste, K., Bezuidenhout, M., (2006). Health Care Service Management. US: Juta and Company Ltd.

Niles, NJ., (2012). Basic Concept of Health Care Human Resource Management. US: Jones \& Bartlett Publishers.

Ramadevi, D., Gunasekaran, A., Roy, M., Rai, B., Senthilkumar, S., (2016), "Human resource management in a healthcare environment: framework and case study," Industrial and Commercial Training, Vol. 48 No. 8, pp. 387393. https://doi.org/10.1108/ICT-03-2016-0014

Rivenbark, L., (2005). “The 7 Hidden Reasons Why Employees Leave," HR Magazine, May 2005.

Online:

http://findarticles.com/p/articles/mi_m3495/is_5_50/ai_n13721406.

[Accessed October 10, 2019].

Robinson, D., (1997). "HR information systems: stand and deliver" Institute for Employment Studies, Report 335, IES, Brighton 


\section{QALAAI ZANISTSCIENTIFIC JOURNAL \\ A Scientific Quarterly Refereed Journal Issued by Lebanese French University - Erbil, Kurdistan, Iraq \\ Vol. (5), No (2), Spring 2020 \\ ISSN 2518-6566 (Online) - ISSN 2518-6558 (Print)}

Rondeau, K., Wagar, T., (2001). Impact of HRM Practices on Nursing Home Performance. Health Services Management Research 2001; 14 (3): 192202.

Samaddar, P., Chauhan, S., Garg, P., (2018). Role of Human Resource Management in Private Hospital's: A Study of Meerut Region, Indian Journal of Applied Research: 10(8): 416-418

Schmitz, A., (2012). Human Resource Management. US: Saylor Academy Publisher.

Sharma, DK., Goyal, RC., (2010). "Evolution of Human Resource Management and its role in Hospitals," Hospital Administration and Human Resource Management, $5^{\text {th }}$ ed. New Delhi, Pub: PHI Learning Private Limited. 161174

Shi, L., (2007). Managing Human Resources in Health Care Organizations. US: Jones \& Bartlett Publishers.

Sun, YS., Nam, CJ., (2011). "The Effects of Human Resource Development on Operational and Financial Performance of Manufacturing Companies: A Large-Scale, Longitudinal Analysis," The Institute for Research on Labor and Employment, UC Los Angeles, 2011. Available online: http://www.escholarship.org/uc/item/5xz8p7bk. [Accessed October 2019].

Townsend, K., Lawrence, S., Wilkinson, A., (2013). The role of hospitals' HRM in shaping clinical performance: a holistic approach, The International Journal of Human Resource Management, 24:16, 30623085, DOI: 10.1080/09585192.2013.775028.

Townsend, K., Wilkinson, A., (2010). Managing under pressure: HRM in hospitals. Human Resource Management Journal, 20(4), 332-333. 


\section{QALAAI ZANISTSCIENTIFIC JOURNAL \\ A Scientific Quarterly Refereed Journal Issued by Lebanese French University - Erbil, Kurdistan, Iraq \\ Vol. (5), No (2), Spring 2020 \\ ISSN 2518-6566 (Online) - ISSN 2518-6558 (Print)}

Vahdat, S., Tabibi, J., Vatan-Khah, S., Hessam, S., Nasiripour, A. (2011). Factors Affecting HRD in the Iranian Social Security Organization's Hospitals. World Appl. Sci. J., 15 (2): 164-173

Valverde, M., Ryan, G., (2006). Distributing HRM responsibilities: a classification of

organizations, Universitat Rovira Virgili, Department of Business, Avinguda Universitat, Tarragona, Spain, Vol. 35 No. 6, Emerald Group Publishing Limited.

West, M., Guthrie, J., Dawson, J., Borrill, C., Carter, M., (2006). Reducing Patient Mortality in Hospitals- The Role of Human Resource Management. Journal of organizational behavior, First published: 21 September 2006, https://doi.org/10.1002/job.396.

World Health Organization: World Health Report, (2000). Health Systems: Improving Performance. Geneva 2000. Available online: [http://www.who.int.proxy.lib.uwo.ca:2048/whr/2000/en/whr00_ch4_e n.pdf]. [Accessed October 2019].

Zurn, P., Dal, MR., Stilwell, A., (2004). Imbalance in the health workforce. Human Resources for Health, 2004, 2:13. 


\section{QALAAI ZANISTSCIENTIFIC JOURNAL}

A Scientific Quarterly Refereed Journal Issued by Lebanese French University - Erbil, Kurdistan, Iraq

كهرتى خاوديّرى تهندروستى دا ، سامانه مروّييهكان روّليّكى خالاكيان ههيه بوّ

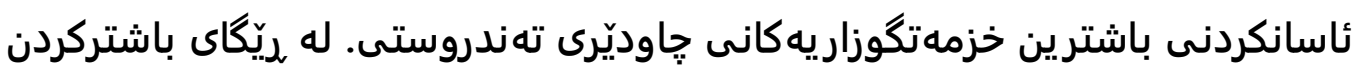

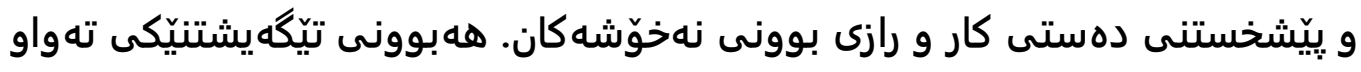

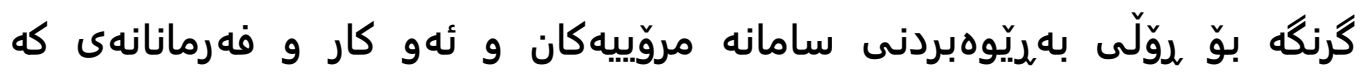
يه يوهنديان ههيه بهو بوارهوه. ئهمه بوّ مهبهستى يِيشكهشكردنى خزمهتكوزارى كواليّت بهرز و سهركهوتنى يروّكرامى جاوديّرى تهندروستى يه. نامانجى ئهو

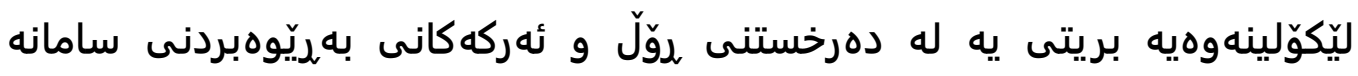

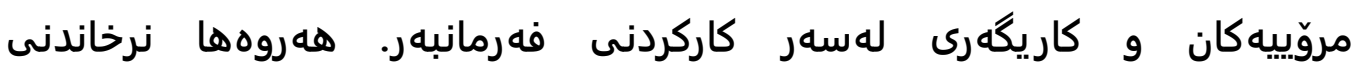

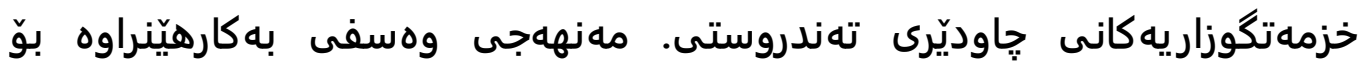

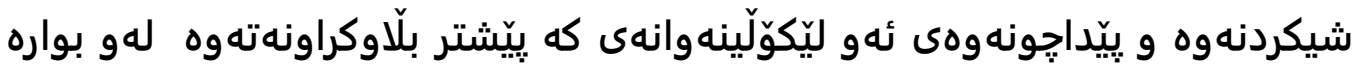

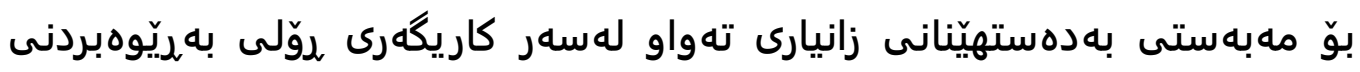
سامانه مروّييهكان له كهرتى تاوديّرى تهندروستى. ليّكوّلينهوهكه ئهوه دهردهخات كهوا روّل و كارهكانى بهريّوهبردنى سامانه مروّييهكان له كهرتى جاوديّرى تهندروستى كاريكهرييهكى گهورهى ههيه لهسهر ناسانكردنى باشترين خزمهتكوزارى קاوديّريه تهندروستى يهكان و كاركردنى دهستى كار، له دهرئهزجام دهبيّته هوّى زيادبوونى كاركردنى ريّكخراوهيى. ليّكوّلينه وهكه يِيّشنيارى ئهوه دهكات كه يِيّويسته

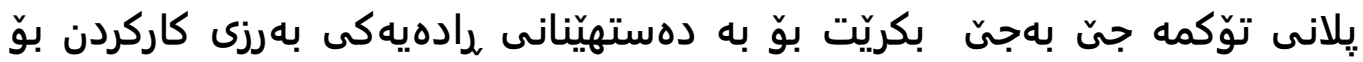

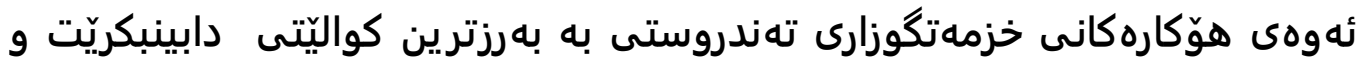

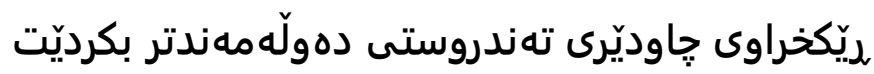




\section{QALAAI ZANISTSCIENTIFIC JOURNAL}

A Scientific Quarterly Refereed Journal Issued by Lebanese French University - Erbil, Kurdistan, Iraq

Vol. (5), No (2), Spring 2020

ISSN 2518-6566 (Online) - ISSN 2518-6558 (Print)

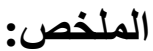

ان دور إدارة الموارد البشرية (HRM) في قطاع الرعاية الصحية أمر حيوي لتسهيل خدمات الرعاية الصحية الافضل و ذلك من خلال تحسين أداء القوى العاملة ورضا المرضى. من المطلوب فهم جيد لدور إدارة الموارد البشرية والوظائف ذات الصلة للحفاظ على تقديم جودة الخدمة ونجاح برنامج الرعاية الصحية. تهدف هذة الدراسة إلى استكشاف دور ومسؤوليات إدارة الموارد البشرية وتأثيرها على أداء الموظف وقيمة خدمات الرعاية الصحية. تم تطبيق المنهج الوصفي و الاستكشافى لتحليل ومراجعة الدرسات السابقة للحصول على تأثير إدارة الموارد البشرية على قطاع الرعاية الصحية. قد اوضح الدراسة أن وظائف إدارة الموارد البشرية في الرعاية

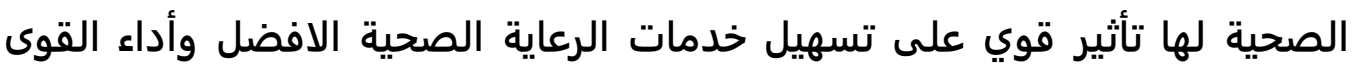
العاملة، مما يؤدي إلى زيادة الأداء التنظيمي. كما توصي الدراسة بضرورة تنفيذ

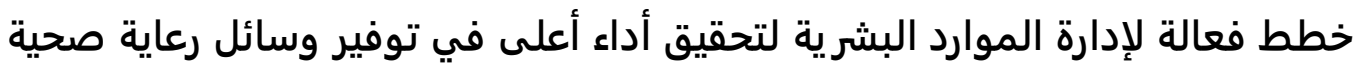
فائقة ومزيد من تعزيزات منظمة الرعاية الصحيةله 